ENCYCLOPÉDIE Encyclopédie berbère

BERBERE

32 | 2010

32 | Mgild - Mzab

Mohand-ou-El Hocine

Muḥend u Lḥusin (Ššix) (saint kabyle)

\title{
OpenEdition
}

Journals

Édition électronique

URL : https://journals.openedition.org/encyclopedieberbere/619

DOI : 10.4000/encyclopedieberbere.619

ISSN : 2262-7197

Éditeur

Peeters Publishers

Édition imprimée

Date de publication : 31 décembre 2010

Pagination : 5047

ISBN : 978-90-429-2369-0

ISSN : 1015-7344

Référence électronique

"Mohand-ou-El Hocine », Encyclopédie berbère [En ligne], 32 | 2010, mis en ligne le 31 décembre 2015,

consulté le 17 février 2022. URL : http://journals.openedition.org/encyclopedieberbere/619 ; DOI

https://doi.org/10.4000/encyclopedieberbere.619

Ce document a été généré automatiquement le 17 février 2022.

(c) Tous droits réservés 


\section{Mohand-ou-El Hocine}

Muḥend $u$ Lḥusin (Ššix) (saint kabyle)

Cf. Hommes et femmes de Kabylie, Dictionnaire biographique de la Kabylie, I, S. Chaker (dir.), Aix-en-Provence, Edisud, 1981: Notice Mohand-ou-El Hocine, par K. Bouamara, p. 171-174. 